\title{
Effect of Lime and Soil Conditioners on Crop Yields and Soil Aggregation
}

\author{
M. A. Lugo-López, J. A. Bonnet, and R. Pérez-Escolar ${ }^{1}$
}

INTRODUCTION

The use of lime in acid soils has always been considered a sound agricultural practice, but differential plant responses have been generally obtained. The recently developed synthetic soil conditioners are either calcium or sodium salts or organic polymers. There are a large number of formulations on the market most of which are either on the basis of a hydrolyzed polyacrilonitril polymer (HPAN) or of a modified vinyl acetate maleic acid (VAMA) compound. The information available so far indicates that the known synthetic soil conditioners stabilize the soil aggregates, but do not form them $(5)^{2}$. Pérez-Escolar and Lugo-López (6) have shown recently that the water stability of the 1-2 mm. aggregates of Juncos clay, a GrayBrown Podzolic soil, was increased by treatment with synthetic polymers. Potatoes increased in yield, but no response was obtained with stringless beans because of the increased stability of soil aggregates. Lugo-López, et al. (4) have reported on the effect of different synthetic conditioners on tobacco seedbeds.

This paper reports the data obtained from a field experiment designed to determine the effect of lime and synthetic soil conditioners on the production of three crops. Studies were also made on the effect of those conditioners on soil-aggregate formation and aggregate stability.

\section{MATERIALS AND METHODS}

The experimental field was located on the farm of the Agricultural Experiment Substation near the town of Corozal, in the humid mountainous interior of the Island (fig. 1). The soil was a nearly level Lares clay, a medium acid and friable Red and Yellow Podzolic (7) soil occurring in

1 Associate Soil Scientist, Head of the Department of Soils, and Research Assistant in Soils, respectively, Agricultural Experiment Station, University of Puerto Rico, Río Piedras, P. R. Appreciation is expressed to the following staff members: $H$. Gandia, Associate Horticulturist, formerly in charge of the Corozal Agricultural Experiment Substation farm, for his general supervision of the fieldwork; $R$. Olivencia, formerly Research Assistant in Agronomy, for his participation in most of the ficldwork relating to the first 3 crops; A. Riera, Associate Chemist in Charge of the Central Analytical Laboratory, formerly with the Department of Soils; and J. P. Rodríguez, Associate Agronomist, who gave valuable help in connection with the first cotton crop. A. Rodriguez Cabrera, Associate Agronomist in Charge of the Corozal Substation, provided the rainfall data.

2 Italic numbers in parentheses refer to Literature Cited, p. 188. 
terrace formations and derived from material washed from the Lower Tertiary clays and shales. Mineralogical studies have revealed that feldspars are absent in this soil and kaolinite dominates the clay fraction ( 8 ). The exchange capacity ranges from 16 to 23 m.e. per $100 \mathrm{gm}$. of dry soil, and the clay content from 35 to 45 percent.

The experiment was laid out following a 4-by-5 duplicated almost balanced, rectangular lattice design, including 20 treatments (10 limed and

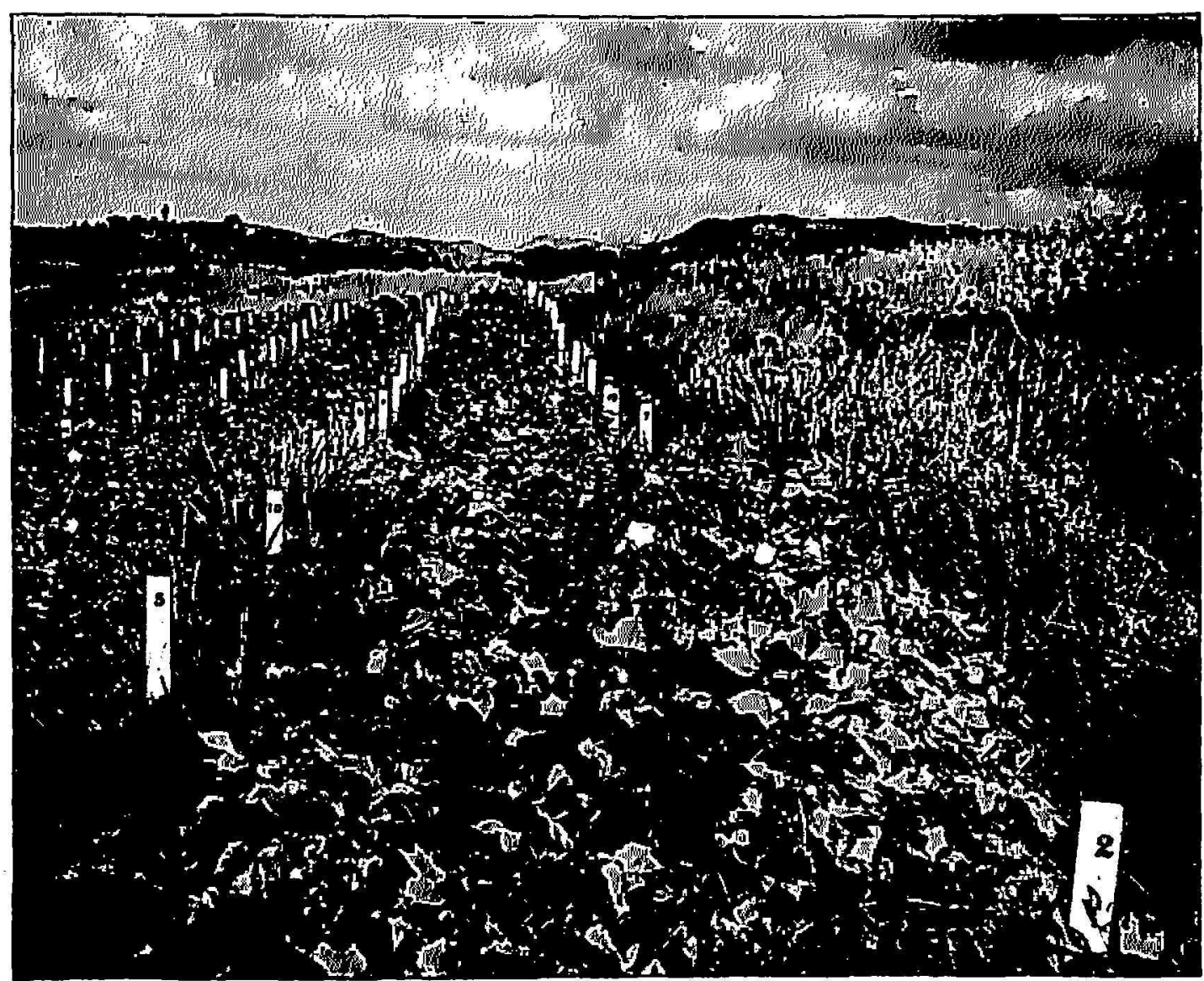

Fig. 1.-General view of the soil-conditioner and lime experimental field at Corozal, P. R., Dec. 7, 1953, with second crop in flower. Plots were only 6 by 4 feet.

10 unlimed) each replicated 10 times. The plots were 6 feet $\times 4$ feet in size. Three soil conditioners were used: Formulations 6 and 9 of Krilium, dry powder, 100-percent active ingredient; and Aerotil, dry powder, 40percent active ingredient. Each conditioner was used at three rates: 900 , 1,800 , and 3,600 pounds to the acre. The conditioners were applied on September 2 and 3,1952, and were carefully mixed with the uppermost 6 inches of soil. The check plots received the same mechanical treatment as the treated plots to minimize any possible differences other than those imposed by other treatments. On October 1, 1952, the limed plots received ground limestone at the rate of 5 tons to the acre. 
Five crops were grown on the same plots in the following sequence: Sweetpotatoes, cotton, cotton (ratoon crop), sweetpotatoes, and corn. Information on each of the crops as to planting and harvesting dates, varieties, and rainfall is reported in table 1.

Sweetpotatoes (first and fourth crops) were planted at the rate of 10,840 plants to the acre; the first crop received an 8-6-16 fertilizer at the rate of 600 pounds to the acre, while the fourth received a 14-4-7 at the rate of 680 pounds. Sealand cotton (second crop) seeds were scorched with concentrated sulfuric acid prior to planting; five seeds were set on each hill to allow thinning to two plants per hill. Twenty days after planting, an 8-6-10 fertilizer was applied at the rate of 800 pounds to the acre, followed

TABLE 1.-General information on the crops grown in the lime and soil-conditioner experiment at the Corozal Substation

\begin{tabular}{|c|c|c|c|c|c|}
\hline $\begin{array}{l}\text { Crop } \\
\text { No. in } \\
\text { se- } \\
\text { quence }\end{array}$ & Crop & Variety & Planting date & Harvesting date & $\begin{array}{l}\text { Rainfall } \\
\text { during } \\
\text { growing } \\
\text { period }\end{array}$ \\
\hline & & & & & Inclies \\
\hline 1 & Sweetpotato & UPR No. 3 & Oct. 9,1952 & Feb. 11, 1953 & $16.1^{1}$ \\
\hline 2 & Cotton & Sealand & Mar. 21, 1953 & $\begin{array}{c}\text { July 31, Aug. 5, } \\
8,11,20,26, \\
\text { and } 28,1953\end{array}$ & 37.6 \\
\hline $3^{2}$ & do. & do. & - & $\begin{array}{c}\text { Jan. } 12,19 \text {, and } \\
\text { Feb. } 4,1954\end{array}$ & 32.3 \\
\hline 4 & Sweetpotato & UPR No. 3 & Feb. 20, 1954 & June 23, 1954 & 16.2 \\
\hline 5 & Corn & Mayorbela & July 15,1954 & Oct. 18,1954 & 24.8 \\
\hline
\end{tabular}

1 Records missing for Oct. 9 to $31,1952$.

${ }^{2}$ A ratoon crop.

by an application of 45 pounds of ammonium sulfate per acre about 40 days afterwards. A ratoon crop of cotton (third crop) was likewise fertilized, omitting the late dressing with ammonium sulfate. Corn (the fifth crop) was thinned down to two plants per hill and received a 9-10-5 fertilizer at the rate of 800 pounds to the acre. All other agronomic practices followed the official recommendations of the Station (2).

Soil samples were taken on December 1, 1953, from check plots and from those unlimed plots that received 3,600 pounds of conditioner per acre. These samples were taken when the second cotton crop was standing on the field, 9 months after the first sweetpotato crop was harvested, i.e., approximately 15 months after the conditioners were applied.

Dry-aggregate distribution was obtained by passing the air-dry soil through a nest of sieves ranging from 0.5 to $5 \mathrm{~mm}$. Aggregate stability was determined in the 2 -to- $0.5 \mathrm{~mm}$. size according to a modification of the 
method proposed by Bryant, Bendixen, and Slater (1). This procedure requires that the aggregates be soaked for 2 minutes and be submitted subsequently to wet screening for 15 minutes. The aggregates remaining in the $0.5-\mathrm{mm}$. sieve are oven-dried at $105^{\circ} \mathrm{C}$. The percentage aggregate stability was determined by dividing this weight by that of the original aggregates.

TABLE 2.-Dry-aggregate distribution in Lares clay from the soilconditioner experiment at Corozal

\begin{tabular}{l|c|c|c|c|c|c|c}
\hline \multicolumn{2}{c|}{ Treatment } & \multicolumn{6}{|c}{ Aggregates of indicated diameter in mm.- } \\
\cline { 2 - 8 } Conditioner & Rate per acre & $>5$ & $3-5$ & $2-3$ & $1-2$ & $0.5-1$ & $<0.5$ \\
\hline & Lb. & Percent & Percent & Percent & Percent & Percent & Percent \\
Check & 0 & 51.5 & 14.6 & 5.3 & 13.8 & 8.5 & 6.3 \\
Krilium 9 & 3,600 & 44.6 & 15.9 & 5.8 & 15.5 & 10.5 & 7.7 \\
Krilium 6 & 3,600 & 42.3 & 16.2 & 7.0 & 15.2 & 10.8 & 8.5 \\
Aerotil & 3,600 & 42.2 & 15.8 & 6.3 & 15.5 & 11.3 & 8.9 \\
\hline
\end{tabular}

TABLE 3.-Water-stable aggregates on Lares clay as affected by trealment with soil conditioners

\begin{tabular}{l|c|c}
\hline \multicolumn{2}{c|}{ Treatment } & Water-stable aggregates, 2-1 mm. \\
\hline Conditioner & Rate per acre & Percent \\
\cline { 2 - 3 } & Lb. & 25.2 \\
Aerotil & 0 & 32.2 \\
Krilium 6 & 3,600 & 48.3 \\
Krilium 9 & 3,600 & 55.0 \\
\hline
\end{tabular}

\section{EXPERIMENTAL RESULTS}

\section{AGGREGation AND AGGREGATE STABILITY}

Table 2 presents the data obtained by dry sieving the Lares clay samples. No appreciable differences in aggregation attributable to treatment were measured. Large aggregates, over $5 \mathrm{~mm}$. in diameter, made up approximately half of the whole soil, the 2-3-mm. aggregate-size fraction was the least abundant and there were not too many fine $(0.5 \mathrm{~mm}$.) aggregates.

Date on soil-aggregate stability are presented in table 3 . The waterstable aggregates in the soil from control plots amounted to only 25 percent, increasing to 32 percent in the Aerotil-treated plots, and to 48 and 55 percent in the plots that received Krilium formulations 6 and 9, respectively. The mean differences in water-stable aggregates are very marked. 
The effect of soil conditioners on the different crops is shown by the mean yields reported in table 4. Over-all significant differences were observed in the mean yields of both crops (Nos. 1 and 4) of sweetpotatoes. In the first crop and in the absence of lime, Krilium 9, at the rate of 1,800 pounds to

TABLE 4.-Mean yields of 5 crops grown in acid Lares clay with soil conditioners and limed or unlimed

\begin{tabular}{|c|c|c|c|c|c|c|c|}
\hline \multirow{2}{*}{$\begin{array}{c}\text { Treat- } \\
\text { ment } \\
\text { identifi- } \\
\text { cation } \\
\text { No. }\end{array}$} & \multirow[b]{2}{*}{ Treatment ${ }^{1}$} & \multirow[b]{2}{*}{$\begin{array}{c}\text { Rates } \\
\text { per acre }\end{array}$} & \multicolumn{5}{|c|}{ Yields of indicated crop per acre } \\
\hline & & & $\begin{array}{l}\text { Crop 1, } \\
\text { sweet- } \\
\text { potato }\end{array}$ & $\begin{array}{l}\text { Crop 2, } \\
\text { cotton }\end{array}$ & $\begin{array}{c}\text { Crop 3, } \\
\text { cotton } \\
\text { (ratoon) }\end{array}$ & $\begin{array}{l}\text { Crop 4, } \\
\text { sweet- } \\
\text { potato }\end{array}$ & $\begin{array}{c}\text { Crop 5, } \\
\text { corn }\end{array}$ \\
\hline & & Pounds & Cwt. & Crot. & Cwt. & Cwt. & Crot. \\
\hline 1 & Check & & 115.5 & 13.7 & 3.5 & 69.1 & 4.7 \\
\hline 2 & Krilium 9 & 3,600 & 115.6 & 21.7 & 5.8 & 105.4 & 5.9 \\
\hline 3 & do. & 1,800 & 139.4 & 20.1 & 4.6 & 107.4 & 4.3 \\
\hline 4 & do. & 900 & 130.7 & 13.4 & 4.2 & 98.1 & 2.4 \\
\hline 5 & Krilium 6 & 3,600 & 122.5 & 15.3 & 4.7 & 116.3 & 13.5 \\
\hline 6 & do. & 1,800 & 127.2 & 16.9 & 3.5 & 105.8 & 3.1 \\
\hline 7 & do. & 900 & 128.1 & 19.2 & 4.6 & 100.4 & 6.2 \\
\hline 8 & Aerotil & 3,600 & 143.3 & 12.6 & $\mathbf{5 . 0}$ & 101.8 & 2.5 \\
\hline 9 & do. & 1,800 & 115.2 & 21.3 & 4.6 & 103.1 & 4.6 \\
\hline 10 & do. & 900 & 129.6 & 18.6 & 4.9 & 94.7 & 1.6 \\
\hline 11 & Lime $^{1}$ & & 138.0 & 24.3 & 4.8 & 110.9 & 7.2 \\
\hline 12 & Lime + Irrilium 9 & 3,600 & 140.2 & 26.1 & 4.9 & 141.1 & 7.3 \\
\hline 13 & do. & 1,800 & 152.0 & 26.6 & 5.7 & 116.2 & 8.4 \\
\hline 14 & do. & 900 & 135.6 & 24.4 & 5.2 & 113.7 & 6.3 \\
\hline 15 & Lime + Krilium 6 & 3,600 & 132.9 & 23.5 & 5.1 & 130.6 & 6.8 \\
\hline 16 & do. & 1,800 & 161.3 & 24.3 & 4.9 & 132.2 & 7.1 \\
\hline 17 & do. & 900 & 146.0 & 21.4 & 4.2 & 141.0 & 9.1 \\
\hline 18 & Lime + Aerotil & 3,600 & 141.7 & 25.6 & 4.6 & 109.6 & 6.5 \\
\hline 19 & do. & 1,800 & 142.1 & 27.5 & 5.3 & 120.8 & 10.3 \\
\hline 20 & do. & 900 & 124.8 & 27.6 & 4.1 & 117.8 & 4.3 \\
\hline \multirow{2}{*}{\multicolumn{3}{|c|}{$\begin{array}{l}\text { L.S.D. at the } 5 \text {-percent level } \\
\text { L.S.D. at the } 1 \text {-percent level }\end{array}$}} & 20.3 & 4.7 & 1.8 & 28.7 & 5.4 \\
\hline & & & 26.8 & 6.2 & 2.4 & 37.9 & 7.2 \\
\hline
\end{tabular}

${ }^{1}$ Lime applied at a rate of 5 tons per acre in treatments 11 to 20 .

the acre outyielded Aerotil at the same rate, Krilium 9 at the highest rate, and the check. The highest level of Aerotil outyielded those same treatments and also the highest rate of Krilium 6 . In the presence of lime, Krilium 6 and 9 at the rate of 1,800 pounds outyielded the lowest level of Aerotil. Krilium 6 at the medium level also outyielded its highest level and the check. In the other sweetpotato crop, and in the absence of lime, all conditioner-treated plots, except the one with the minimum rate of Aerotil, outyielded the check. In the presence of lime, Krilium 9 at the maximum 
TABLE 5.-Mean yields of 5 crops grown on Lares clay, limed and unlimed, with soil conditioners, irrespective of rates

\begin{tabular}{|c|c|c|c|c|}
\hline \multirow{2}{*}{ Treatment } & \multicolumn{2}{|c|}{ Yields per acre } & \multicolumn{2}{|c|}{ L.S.D. at the indicated level } \\
\hline & Unlimed & Limed & 5-percent & 1-percent \\
\hline \multicolumn{5}{|c|}{ Crop 1-Sweetpotatoes } \\
\hline $\begin{array}{l}\text { Check } \\
\text { Krilium } 9 \\
\text { Krilium } 6 \\
\text { Aerotil }\end{array}$ & $\begin{array}{c}\text { Czot. } \\
115.5 \\
128.6 \\
125.9 \\
129.4\end{array}$ & $\begin{array}{c}\text { Cwt. } \\
138.0 \\
142.6 \\
146.7 \\
136.2\end{array}$ & \begin{tabular}{r|}
20.3 \\
8.3 \\
8.3 \\
8.3
\end{tabular} & $\begin{array}{l}26.8 \\
10.9 \\
10.9 \\
10.9\end{array}$ \\
\hline \multicolumn{5}{|c|}{ Crop 8-Colton } \\
\hline $\begin{array}{l}\text { Check } \\
\text { Krilium } 9 \\
\text { Krilium } 6 \\
\text { Aerotil }\end{array}$ & $\begin{array}{l}13.7 \\
18.4 \\
17.1 \\
17.5\end{array}$ & $\begin{array}{l}24.3 \\
25.7 \\
23.1 \\
26.9\end{array}$ & $\begin{array}{l}4.7 \\
1.9 \\
1.9 \\
1.9\end{array}$ & $\begin{array}{l}6.2 \\
2.5 \\
2.5 \\
2.5\end{array}$ \\
\hline \multicolumn{5}{|c|}{ Crop s-Cotton (ratoon) } \\
\hline $\begin{array}{l}\text { Check } \\
\text { Krilium } 9 \\
\text { Krilium } 6 \\
\text { Aerotil }\end{array}$ & $\begin{array}{l}3.5 \\
4.9 \\
4.3 \\
4.8\end{array}$ & $\begin{array}{l}4.8 \\
5.3 \\
4.7 \\
4.7\end{array}$ & $\begin{array}{r}1.8 \\
.7 \\
.7 \\
.7\end{array}$ & $\begin{array}{l}2.4 \\
1.0 \\
1.0 \\
1.0\end{array}$ \\
\hline
\end{tabular}

Crop 4-Sweetpotatoes

\begin{tabular}{|c|c|c|c|c|}
\hline $\begin{array}{l}\text { Check } \\
\text { Krilium } 9 \\
\text { Krilium } 6 \\
\text { Aerotil }\end{array}$ & $\begin{array}{r}69.1 \\
103.6 \\
107.5 \\
99.6\end{array}$ & $\begin{array}{l}110.9 \\
123.7 \\
134.6 \\
116.1\end{array}$ & $\begin{array}{l}28.7 \\
11.7 \\
11.7 \\
11.7\end{array}$ & $\begin{array}{l}37.9 \\
15.5 \\
15.5 \\
15.5\end{array}$ \\
\hline \multicolumn{5}{|c|}{ Crop 5-Corn } \\
\hline $\begin{array}{l}\text { Check } \\
\text { Krilium } 9 \\
\text { Krilium } 6 \\
\text { Aerotil }\end{array}$ & $\begin{array}{l}4.7 \\
4.2 \\
7.6 \\
2.9\end{array}$ & $\begin{array}{l}7.2 \\
7.3 \\
7.7 \\
7.3\end{array}$ & $\begin{array}{l}5.4 \\
2.2 \\
2.2 \\
2.2\end{array}$ & $\begin{array}{l}7.2 \\
2.7 \\
2.7 \\
2.7\end{array}$ \\
\hline $\begin{array}{r}\text { L.S.D. between any treatment } \\
\text { cated levels for each crop: } \\
\text { Crop 1 } \\
\text { Crop 2 } \\
\text { Crop 3 } \\
\text { Crop 4 } \\
\text { Crop 5 } \\
\text { L.S.D. between any two treatm } \\
\text { levels, excluding checks, for e } \\
\text { Crop 1 } \\
\text { Crop 2 } \\
\text { Crop 3 } \\
\text { Crop 4 } \\
\text { Crop 5 }\end{array}$ & $\begin{array}{l}\text { an and } \\
\text { ts mea } \\
\text { crop: }\end{array}$ & $\begin{array}{l}\text { at indi } \\
\text { ndicatec }\end{array}$ & $\begin{array}{r}16.6 \\
3.8 \\
1.5 \\
23.4 \\
4.4\end{array}$ & $\begin{array}{r}21.9 \\
5.1 \\
2.0 \\
30.9 \\
5.9\end{array}$ \\
\hline
\end{tabular}


level and Krilium 6 at the minimum level outyielded Aerotil at the maximum level and the check.

In the first cotton crop, the second in the sequence, highly significant differences in yields were measured which could be attributed to soil conditioners. In the unlimed plots, Krilium 9 at both the medium and highest levels, Krilium 6 at the lowest level, and Aerotil at the lowest and medium levels outyielded the check, the lowest level of Krilium 9 and the highest level of Aerotil, respectively. Krilium 9 and Aerotil at the medium level outyielded the highest level of Krilium 6; and the highest level of Krilium 9 outyielded the medium level of Krilium 6 . In the presence of lime, none of the conditioners outyielded the check; but the lowest level of Aerotil outyielded that for Krilium 6 .

In the second cotton crop, a ratoon, third in the sequence, yields dropped

TABLE 6.-Effect of lime application to acid Lares clay on the mean yields of various consecutive crops

\begin{tabular}{|c|c|c|c|c|c|}
\hline \multirow{2}{*}{ Crop } & \multirow{2}{*}{$\begin{array}{l}\text { Crop No. in } \\
\text { sequence }\end{array}$} & \multicolumn{2}{|c|}{$\begin{array}{l}\text { Yield from indicated } \\
\text { trea tment per acre }\end{array}$} & \multicolumn{2}{|c|}{$\begin{array}{l}\text { L.S.D. at the indicated } \\
\text { level }\end{array}$} \\
\hline & & Unlimed & Limed & 5-percent & 1-percent \\
\hline & & Cwot. & Cwot. & & \\
\hline $\begin{array}{l}\text { Sweetpotato } \\
\text { Cotton }\end{array}$ & $\begin{array}{l}1 \\
2\end{array}$ & $\begin{array}{r}126.7 \\
17.3\end{array}$ & $\begin{array}{r}141.5 \\
25.1\end{array}$ & $\begin{array}{l}6.4 \\
1.5\end{array}$ & $\begin{array}{l}8.5 \\
1.9\end{array}$ \\
\hline Cotton (ratoon) & 3 & 4.5 & 4.9 & .6 & .8 \\
\hline Sweetpotato & 4 & 100.2 & 123.4 & 9.1 & 12.0 \\
\hline Corn & 5 & 4.9 & 7.4 & 1.7 & 2.3 \\
\hline
\end{tabular}

abruptly from approximately 17 hundredweights to the acre in the previous crop to 4 in the unlimed plots and from 25 to approximately 5 in the limed plots, irrespective of soil-conditioner treatments. Only the highest level of Krilium 9 outyielded that of Krilium 6 and the check.

In the corn crop, the fifth in the sequence, over-all mean differences were significant. Krilium 6 at the highest level outyielded the check and all other treatments in the absence of lime. In the presence of lime, only Aerotil at the medium level, outyielded the lowest level.

Table 5 shows the mean crop yields, comparing the general effect of each of the conditioners, irrespective of the rates used. In the first sweetpotato crop, in the absence of lime, differences were not quite significant, but they were significant in the other sweetpotato crop, the fourth in the sequence. In the cotton plant crop, in the absence of lime, the over-all effect of soil conditioners was significant, but not in the ratoon crop. In the corn crop, differences were not significant. Krilium 6 was significantly better than Aerotil in the last two crops and better than Krilium 9 in the last crop. 


\section{LIME AND CROP YIELDS}

Differences attributable to the effect of soil conditioners were minimized in the presence of lime (table 5); generally the yields were higher in the limed plots. Lack of lime was a limiting factor for crop production in acid Lares clay.

The effects of lime applications upon sweetpotato, cotton, and corn yields are summarized in table 6 . The mean yield differences are highly significant for all crops except for the ratoon cotton crop, the third in the sequence.

\section{DISCUSSION}

The data in table 2 support the hypothesis that the more commonly known soil conditioners do not form aggregates. No differences in degree of aggregation due to treatments were observed in the soils when sampled some 15 months after establishing the treatment differentials. However, rather large differences were measured in the water-stability of soil aggregates (table 3). The study of the effect of synthetic conditioners on aggregate stability was restricted in this work to soil from check plots and from those where the chemicals were used at the maximum rate. However, information from a somewhat similar experiment at Aibonito revealed increases in aggregate stability at all three levels of the same conditioners (6).

All the crops in the sequence, except the third-a ratoon cotton cropshowed good, although variable responses to the application of soil conditioners. Sweetpotato, a root crop, was more responsive to the structure improvement resultant from the use of soil conditioners; the cotton plant crop responded also. The use of lime in this acid soil produced by far the most satisfactory results. Crop yields were boosted to over 10 and 20 percent in the sweetpotato crops, over 45 in the first cotton crop, and 50 in the corn crop. Yield increases for all crops attributable to lime were observed either in the presence or absence of any conditioner, irrespective of the levels used.

Widespread use of synthetic soil conditioners in general farming is currently limited by their cost. For a long while they will be necessarily restricted to specialized uses, but they can be of value in problem soils. The stabilization of structural units promotes a rather favorable physical environment in the soil. It improves soil-moisture movement, insures adequate aeration, and favors root extension, thus allowing the plant to exploit a larger volume of soil in its search for vital nutrients and moisture. The differential response of plants to increased soil-aggregate stability must be recognized (6). The possibilities of using cheaper organic materials such as filter-press cake, bagasse, sawdust, and crop residues, for the improvement 
of soil structural conditions rather than using the costly synthetic products must be investigated. Furthermore, lime is relatively inexpensive in Puerto Rico. If the yields of some crops in acid soils could be boosted by the use of lime, in addition to the regular rational fertilization, it does not appear that synthetic materials have economic possibilities.

\section{SUMMARY}

Data are presented here on the effect of synthetic soil conditioners on aggregation and aggregate stability of acid Lares clay and on their effect, with or without lime, on the yields of sweetpotatoes, cotton, and corn.

Three conditioners were used: Formulations 6 and 9 of Krilium, and Aerotil, dry form, each at the rates of $900,1,800$, and 3,600 pounds to the acre. There were 20 treatments: Check, lime, conditioners at three levels, and conditioners at the same three levels plus lime. The data presented indicate that these conditioners will stabilize soil structural units, but will not form them.

Five crops were grown as a sequence: Sweetpotatoes, cotton, cotton (a ratoon crop), sweetpotatoes, and corn. All crops, except the cotton ratoon, showed some response to the application of soil conditioners. Sweetpotato, a root crop, was more responsive; but the cotton plant crop responded also to stabilized good structural soil conditions.

The largest crop responses measured were in the limed treatments. Increases attributable to lime were obtained either in the presence or absence of synthetic soil conditioners. Liming and rational fertilization seems to be the key to increased productivity in some acid soils of Puerto Rico. The synthetic materials do not have practical possibilities in large-scale farming.

\section{RESUMEN}

Se presentan aquí datos sobre el efecto de acondicionadores sintéticos del suelo en la agregación y en la estabilidad de los agregados del suelo Lares arcilloso. Se analiza también el efecto de estos compuestos químicos y de la cal sobre los rendimientos de batata, algodón y maíz en un suelo ácido como el Lares arcilloso.

Los acondicionadores usados fueron Krilium 6 y 9 y Aerotil, cada uno a razón de 900, 1,800 y 3,600 libras por acre. Se incluyeron 20 tratamientos, a saber, testigo y acondicionadores a los tres niveles arriba mencionados sin cal y con cal, a razón de 5 toneladas por acre en cada caso.

Cinco cosechas consecutivas se produjeron en las parcelas después de establecer los tratamientos: Batatas, algodón, algodón (retoño), batatas y maíz. Todas las cosechas, excepto el retoño de algodón, respondieron en alguna forma a la aplicación de los acondicionadores sintéticos al suelo. La batata, una cosecha de raices comestibles respondió mejor, pero aún el 
algodón de plantilla respondió satisfactoriamente a las condiciones mejoradas del suelo, motivadas por una mayor estabilidad de sus unidades estructurales o agregados.

Sin lugar a dudas, fué la cal la que provocó los mayores aumentos en los rendimientos, tanto en ausencia como en presencia de los acondicionadores sintéticos del suelo. El encalar los suelos ácidos, conjuntamente con un programa racional de abonamiento, es la clave para el aumento de la productividad en algunos de los suelos ácidos de Puerto Rico, en cuanto a cosechas como la batata, el algodón y el maíz. Bajo tales condiciones, los acondicionadores de suelos no parecen ofrecer posibilidades prácticas en las operaciones agrícolas en gran escala.

\section{LITERATURE CITED}

1. Bryant, J. C., Bendixen, T. W., and Slater, C. W., Measurement of water stability of soils, Soil Sci. 65 341-5, 1948.

2. Compendio de recomendaciones para la producción de cosechas, Agr. Exp. Sta. Univ. P. R. Misc. Pub. 1 (revised) 1954.

3. Jeffries, C. D., Bonnet, J. A., and Abruña, F., The constituent minerals of some soils of Puerto Rico, J. Agr. Univ. P.R. 37(2) 114-39, 1953.

4. Lugo-López, M. A., Bonnet, J. A., Amy, A. S., and Pérez-Escolar, R., Effect of soil-structure stabilizers on the production of tobacco plants in the seedbed, J. Agr. Univ. P. R., 41(3) 189-96, 1957.

5. Pearson, R. W., and Jamison, V. C., Improving land conditions for conservation and production with chemical soil conditioners, J. Soil \& Water Conserv. 8(3) 130-5, 1953.

6. Pérez-Escolar, R., and Lugo-López, M. A., The effect of synthetic soil conditioners on soil-aggregate stability and production of potatoes and stringless beans, J. Agr. Univ. P. R., 41(2) 127-33 1057.

7. Roberts, R. C., Soil survey of 1'uerto Rico, USDA in cooperation with Univ. of P. R., Agr. Exp. Sta. Series 1936 (8), 1942. 